ノート

\title{
千葉県で捕獲された野生獣肉の放射性セシウム検査について
}

(平成 27 年 10 月 22 日受理)

\author{
林 千恵子 ${ }^{1, *}$ 中村和 宏 $^{1}$ 本郷 猛 ${ }^{1}$ 橋本 博 ${ }^{1}$ \\ 原田利 栄 $^{1}$ 中西希代子 ${ }^{2}$ 石井 俊靖 ${ }^{1}$
}

\section{Surveillance of Radioactive Cesium in Meats of Wild Animals Caught in Chiba Prefecture}

Chieko HAYASHI ${ }^{1, *}$, Kazuhiro NAKAMURA ${ }^{1}$, Takeshi Hongo ${ }^{1}$, Hiroyuki HaShimoto ${ }^{1}$, Rie HARADA ${ }^{1}$, Kiyoko NAKANISHI ${ }^{2}$ and Toshiyasu IshiI ${ }^{1}$

${ }^{1}$ Chiba Prefectural Institute of Public Health: 666-2 Nitona-cho, Chuo-ku, Chiba 260-8715, Japan;

${ }^{2}$ Kashiwa City Public Health Center: Wellness Kashiwa-nai, 65-1 Kashiwashita, Kashiwa, Chiba 277-0004, Japan;

*Corresponding author

From fiscal year 2012 to 2014, we surveyed the concentration of radioactive cesium in 39 wild animal meats obtained from 20 wild boars and 19 deer caught in Chiba prefecture, using a germanium semiconductor detector. Four wild boar meats in the fiscal years 2012 and 2013 exceeded the radioactive cesium limit in general foods $(100 \mathrm{~Bq} / \mathrm{kg})$, whereas none of the deer meats exceeded the limit. The left side of the wild boar that showed a radioactive cesium concentration above $100 \mathrm{~Bq} / \mathrm{kg}$ was divided into 14 parts. We compared the radioactive cesium concentration in the ham used for the screening test with those in other parts. The concentration was highest in ham, among the edible parts.

(Received October 22, 2015)

Key words: 放射性セシウム radioactive cesium; ゲルマニウム半導体検出器 germanium semiconductor detector; イノシシ wild boar; シカ deer; 部位別濃度 concentration by part

\section{はじめに}

平成 23 年 3 月に発生した東日本大震災により，東京電 力福島第一原子力発電所事故が発生し, 周辺環境に放射性 物質が放出され，一部の食品から放射性物質が検出され た。この事故を受け千葉県では県民の健康を守ることを目 的に, 当研究所において新たに検査体制を整備し, 平成 24 年 2 月から食品中の放射性セシウム検査を開始した 当県では野生鳥獣による農作物の被害が増加しており，そ の対策として平成 20 年に千葉県イノシシ肉に係る衛生管 理ガイドライン*1 が策定され, 捕獲したイノシシを食肉 として有効利用する事業が進められてきた。 しかし, 平成 24 年 9,10 月に県内で捕獲されたイノシシ肉から一般食 品の基準值である $100 \mathrm{~Bq} / \mathrm{kg}$ を超える放射性セシウムが検 出され，原子力災害対策特別措置法に基づく出荷制限の指

* 連絡先 c.hysh8@pref.chiba.lg.jp

1 千葉県衛生研究所： T260-8715 千葉市中央区仁戸名町 666-2

2 柏市保健所： テ277-0004 千葉県柏市柏下 65-1ウェルネス 柏内

*1 千葉県イノシシ肉に係る衛生管理ガイドライン, 千葉県野生 鳥獣対策本部

http://www.pref.chiba.lg.jp/noushin/choujuu/yuugai/ documents/guideline.pdf
示があった。そのため，県では新たにイノシシ肉の出荷・ 検査方針*2を定め, 現在は県内 5 か所の野生獣肉処理加工 施設で全頭検査により管理されるイノシシ肉に限り出荷制 限が解除されている，処理加工施設が所在する市町におい て, $\mathrm{NaI}(\mathrm{Tl})$ シンチレーションスペクトロメータを用い たスクリーニング検査 ${ }^{* 3}$ が実施され， $50 \mathrm{~Bq} / \mathrm{kg}$ を超えた ものについては平成 25 年 3 月から当研究所のゲルマニウ 厶半導体検出器で精密検査を行うこととなった。ささに平 成 25 年 5 月からは毎年度策定される野生鳥獣肉検査計 画*4に基づき，食用に供される野生鳥獣肉の安全性を担

*2「検査計画, 出荷制限等の品目 ・ 区域の設定・解除の考え方」 に基づく千葉県産イノシシ肉の出荷・検査方針の見直しにつ いて

http://www.mhlw.go.jp/stf/kinkyu/2r9852000001ddg2-att/ 2r98520000036vvq_1.pdf

*3 食品中の放射性セシウムスクリーニング法の一部改正につい て, 事務連絡, 厚生労働省医薬食品局食品安全部監視安全課 (平成 24 年 3 月 1 日)

*4 千葉県における 25 年度県内処理加工施設で加工される野生 鳥獣肉の放射性物質検査について, 千葉県農林水産部農村環 境整備課

http://www.pref.chiba.lg.jp/nousui/houshaseibussitsu/ documents/5_yaseijuukensakeikaku.pdf 
保するため, スクリーニング検査を実施せず，直接ゲルマ ニウム半導体検出器を用いたシカ肉のモニタリング検査を 開始した。

本報告では, 平成 25 年 3 月から平成 27 年 3 月に実施し た千葉県内で捕獲された野生獣肉の検査状況について取り まとめた。また， $100 \mathrm{~Bq} / \mathrm{kg}$ を超えたイノシシ肉の左半身 を用い，スクリーニング検査対象部位であるモモ肉とモモ 肉以外の複数の部位について, 放射性セシウム $(\mathrm{Cs}) 134$ と 137 の合計濃度や脂質含有量を比較したところ, 有用な 知見が得られたので報告する.

\section{実験方法}

\section{1. 試料}

平成 25 年 2 月から平成 27 年 2 月までに県内で食用とし て捕獲され，スクリーニング検査の結果 $50 \mathrm{~Bq} / \mathrm{kg}$ を超え たイノシシ肉 20 検体および平成 25 年 5 月から平成 27 年 2 月までにモニタリング用として捕獲されたシカ肉 19 検体 を試料とした。また， Cs 濃度合計が $100 \mathrm{~Bq} / \mathrm{kg}$ を超えた イノシシ（捕獲日：平成 25 年 2 月, 性別：オス, 体重： $56 \mathrm{~kg}$ ) の左半身 (冷蔵保管検体, 約 $15 \mathrm{~kg}$ ) を用い, イノ シシ肉出荷・販売台帳*1に記載されている 7 部位, および 一定量の肉の採取が可能であったその他 7 部位の計 14 部 位（Fig. 1）に解体し, 試料とした.さらに, 脂肪のみの $\mathrm{Cs}$ 濃度を把握するため, 脂肪の多い腹の部位から脂肪の みを採取し，脂肪試料とした。

\section{2. 装置・容器等}

ゲルマニウム半導体検出器は, キャンベラ社製 GR2018 （相対効率 $24.8 \%$ ）を用い, データ解析は解析ソフトの $\gamma$ エクスプローラーを用いて行った. 検体の細切・均一化に は，包丁，ミルサー（Iwatani（株）製IFM-77G）を使用 し, 容器はU-8容器 $(100 \mathrm{~mL})$ を使用した。無水硫酸ナ トリウム（残留農薬・PCB試験用）およびジエチルエー テル（試薬特級）は和光純薬工業(株)製を用いた.

\section{3. 野生獣肉の放射性セシウム検査}

検査は通知*5,*6 に基づいて行った。イノジ肉は, NaI （Tl）シンチレーションスペクトロメータによるスクリー ニング検査に使用した脂肪除去後のモモ肉を, そのまま U-8容器に充填した. スクリーニング検査に使用したモモ 肉が入手できなかった検体については，同一個体のモモ肉 のブロックから可能な限り脂肪を除去した笳肉部分を包丁 で細切・均一化し, U-8容器に充填した。 シ力肉もモモ肉 のブロックから可能な限り脂肪を除去した笳肉部分をイノ シシ肉と同様に処理しU-8容器に充填した. イノシシ肉で はスクリーニング検査において $50 \mathrm{~Bq} / \mathrm{kg}$ 以上検出してい

*5 食品中の放射性物質の試験法について, 食安発 0315 第 4 号, 厚生労働省医薬食品局食品安全部長（平成 24 年 3 月 15 日）

*6 食品中の放射性物質に係る基準值の設定に関する Q\&Aにつ いて, 食安基発 0320 第 3 号, 食安監発 0320 第 3 号, 厚生労 働省医薬食品局食品安全部基準審査課長, 監視安全課長（平 成 27 年 3 月 20 日)

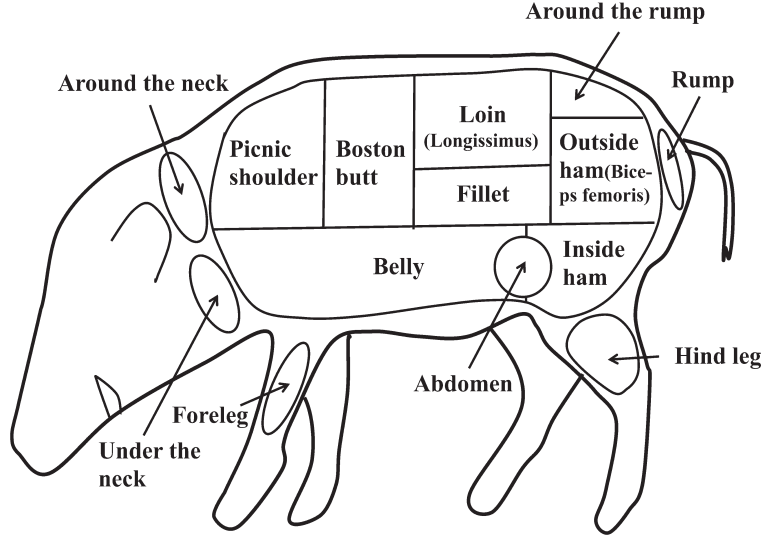

Fig. 1. Part names of wild boar meat

ることが確認されているため, Cs-134 と Cs-137のそれぞ れの測定結果に伴う計数誤差による標準偏差の 2 乗和を分 散とした相対標準偏差（測定值のRSD）が10\%を切った 時点で終了する条件により測定した．また，当研究所にお いて Cs 濃度が確定してから出荷され，食用に供されるこ とから，採取日から測定時までの $\mathrm{Cs}$ の半減期による濃度 減少の補正（減衰補正）は行わなかった。 シ力肉はモニ夕 リング調査であることから，検出限界值未満または低濃度 での検出となる検体が想定された。 そのため測定条件は, Cs-134 と Cs-137の検出限界值の和が一般食品の基準值 $100 \mathrm{~Bq} / \mathrm{kg}$ の $1 / 5$ 以下となるか，測定值の RSDが $10 \%$ を 切った時点で終了するように設定した。 またイノシシ肉と 同様に減衰補正は行わなかった。

\section{4. イノシシ肉部位別の放射性セシウム測定}

14 部位に解体したイノシシ肉は，そのまま細切したも の（脂肪除去前検体）と可能な限り脂肪を除去し細切した もの（脂肪除去後検体）を調製した。また脂肪試料も細切 し，それぞれU-8容器に充填し測定值を比較した。部位別 測定に使用したイノシシ肉は 3,600 秒の測定時間におい て，測定值の RSDが10\%を切ることが確認されたことか ら，過剩な測定時間は不要と判断し，測定時間は一律 3,600 秒とした。また，部位ごとの測定日が異なることか ら, 捕獲日の数值として Cs 濃度を比較するため, 減衰補 正を行った.

\section{5. 脂質含有量の測定}

脂質の定量はエーテル抽出法*7 により実施した。 Cs 濃 度を測定したイノシシ肉をU-8容器から全量取り出し, ミ ルサーを用いて均一化した。均一化した試料 $5 \mathrm{~g}$ を採取 し，適量の無水硫酸ナトリウムと混合して脱水した後，ジ エチルエーテルを溶媒に, ソックスレー抽出器を用いて 8 時間抽出した。溶媒を除去し, 乾燥後の残留物の重量を 脂肪重量とした.

*7 栄養表示基準に扔ける栄養成分等の分析方法等について, 衛 新第 13 号, 新開発食品保健対策室長（平成 11 年 4 月 26 日） 
Table 1. Cs concentration in wild boar meat

\begin{tabular}{|c|c|c|c|}
\hline \multirow{2}{*}{$\begin{array}{l}\text { Fiscal } \\
\text { year }\end{array}$} & \multicolumn{3}{|c|}{ Concentration (Bq/kg) } \\
\hline & Cs-134 & Cs-137 & Total Cs \\
\hline \multirow[t]{3}{*}{2012} & 38.6 & 86.4 & 130 \\
\hline & 89.1 & 169 & 260 \\
\hline & 25.0 & 47.6 & 73 \\
\hline \multirow[t]{16}{*}{2013} & 25.1 & 54.2 & 79 \\
\hline & 33.0 & 60.9 & 94 \\
\hline & 22.8 & 52.8 & 76 \\
\hline & 27.8 & 65.7 & 94 \\
\hline & 18.0 & 43.1 & 61 \\
\hline & 18.1 & 47.4 & 66 \\
\hline & 25.2 & 48.1 & 73 \\
\hline & 16.8 & 54.7 & 72 \\
\hline & 17.4 & 49.9 & 67 \\
\hline & 25.9 & 56.9 & 83 \\
\hline & 40.6 & 114 & 150 \\
\hline & 29.4 & 96.7 & 130 \\
\hline & 18.2 & 54.2 & 72 \\
\hline & 24.6 & 74.5 & 99 \\
\hline & 15.9 & 41.1 & 57 \\
\hline & 14.0 & 45.7 & 60 \\
\hline 2014 & 14.6 & 50.6 & 65 \\
\hline
\end{tabular}

\section{結果および考察}

\section{1. 野生獣肉の放射性セシウム検査}

イノシシ肉の精密検査結果を Table 1 に示す。測定時間 は1,068〜10,805秒の範囲であった. 処理加工施設が所在 する市町におけるスクリーニング検査の結果, $50 \mathrm{~Bq} / \mathrm{kg}$ を超えたのは 334 検体中 20 検体であり, これらのうち 4 検体からは, 一般食品の基準值を超える Cs 濃度が検出さ れた。平成 25 年 2 月に捕獲された 2 検体は, Cs 濃度合計 がそれぞれ $130,260 \mathrm{~Bq} / \mathrm{kg}$, 平成 26 年 1 月に捕獲された 2 検体はそれぞれ $130,150 \mathrm{~Bq} / \mathrm{kg}$ であった。 その他の検 体は 57〜 $99 \mathrm{~Bq} / \mathrm{kg}$ の濃度で検出された.

シカ肉のモニタリング検査結果を Table 2 に示す. 測定 時間は $1,445 〜 28,274$ 秒の範囲であった。 シカ肉は Cs 濃 度合計がN.D.〜28 Bq/kgの範囲であり，一般食品の基準 值を超える Cs 濃度は検出されず, イノシシ肉に比べ検出 濃度は低い傾向を示した。 この結果の違いは, シカが草や 木の芽や葉, 樹皮などを慨にしている1) のに対し, イノシ シは雑食性であり，これまでにCsが検出されている夕ケ ノコ，果実などを飭にし，また Csに污染されたミミズ ${ }^{2)}$

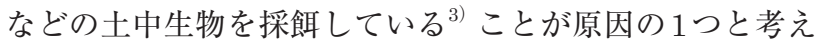
られた。

イノシシ肉とシカ肉の検査結果から, Cs-137に対する Cs-134の存在比率を求めた。平成 25 年 2,3 月に捕獲され た検体では $0.45 \sim 0.53$, 平成 25 年 5 月から平成 26 年 3 月 に捕獲された検体では $0.26 \sim 0.54$, 平成 26 年 6 月から平

\footnotetext{
*8 福島第一原子力発電所 東北地方太平洋沖地震に伴う原子炉 施設への影響について, 東京電力株式会社（平成 24 年 9 月） https://www.nsr.go.jp/data/000024865.pdf
}

Table 2. Cs concentration in deer meat

\begin{tabular}{cccc}
\hline \hline \multirow{2}{*}{$\begin{array}{c}\text { Fiscal } \\
\text { year }\end{array}$} & \multicolumn{3}{c}{ Concentration $(\mathrm{Bq} / \mathrm{kg})$} \\
\cline { 2 - 4 } 2013 & Cs-134 & Cs-137 & Total Cs \\
\hline \multirow{2}{*}{28.0} & $<8.9$ & $<17$ \\
& $<8.9$ & $<7.6$ & $<17$ \\
& $<7.8$ & $<9.2$ & $<17$ \\
& $<7.2$ & $<9.8$ & $<17$ \\
& $<9.2$ & $<7.3$ & $<17$ \\
& $<8.0$ & $<8.8$ & $<17$ \\
& 6.91 & 21.5 & 28 \\
& 4.78 & 15.0 & 20 \\
& 8.53 & 18.3 & 27 \\
& 2.76 & 10.7 & 13 \\
\hline \multirow{2}{*}{2014} & $<8.2$ & $<8.7$ & $<17$ \\
& 2.68 & 11.2 & 14 \\
& $<8.3$ & $<8.5$ & $<17$ \\
& $<7.9$ & $<8.7$ & $<17$ \\
& $<8.4$ & $<8.1$ & $<17$ \\
& $<8.7$ & $<8.0$ & $<17$ \\
& $<8.5$ & $<8.3$ & $<17$ \\
2.04 & 6.08 & 8.1 \\
& $<8.8$ & $<8.0$ & $<17$ \\
\hline
\end{tabular}

成 27 年 2 月に捕獲された検体では $0.24 \sim 0.34$ となった. 福島第一原子力発電所事故により平成 23 年 3 月中に大気 中に放出された Cs- 134 が約 $10 \times 10^{15} \mathrm{~Bq}, \mathrm{Cs}-137$ が約 $10 \times$ $10^{15} \mathrm{~Bq}$ と推定されている*8ことから, その比率を $1: 1$ と し (基準日：3月 11日), 物理学的半減期（Cs-134：約 2 年, Cs-137：約 30年 ${ }^{4)}$ から Cs-137に対するCs-134の存 在比率を求めた場合， 2 年後の平成 25 年 3 月 11 日には $0.54,3$ 年後には $0.39,4$ 年後には 0.29 となる. 検査結果 から求めた值は, 上記計算から求めた理論值とほぼ同様に 推移していた。このことからイノシシ肉とシカ肉から検出 された $\mathrm{Cs}$ 濃度は, 主に福島第一原発事故に起因するもの と推察された.Cs-137の半減期は約 30 年と長く, チェル ノブイリ原発事故後, 20 年以上の長期間にわたりイノシ シの筋肉から Cs が検出されたという報告 ${ }^{5)}$ があることか ら，食用に供されるイノシシ肉については，今後も継続的 な調査が必要と考えられた。

\section{2. イノシシ肉部位別の放射性セシウム濃度および脂質}

\section{含有量}

当研究所では, イノシシ肉の精密検査には脂肪層が少な く検体量が十分に採取できるモモ肉を常用している。そこ で，モモ肉常用の妥当性を確認するために，部位間のCs 濃度差の有無について脂肪除去前検体を用いて検討を行っ た。脂肪除去前検体の Cs 濃度測定結果および脂質含有量 の結果をTable 3 に，その散布図を Fig. 2 に示した. Cs 濃 度はモモ肉を基準とし，その他の部位を比で表した。 Cs 濃度が最も高い部位はモモ肉で, 最も低いのは脂質が多い 腹の部位であった．脂肪試料はさらに低濃度となった。 $\mathrm{Cs}$ 濃度比と脂質含有量の関係は, 相関係数 $r=-0.956$ $(n=15, p<0.05)$ となり，強い負の相関が認められた. 牛肉において, 脂肪含有量の増加に伴い Cs 濃度は低下す 
Table 3. The ratio of Cs concentration and fat content in each part of wild boar meat

\begin{tabular}{llcc}
\hline \hline Part & $\begin{array}{c}\text { Ratio of Cs } \\
\text { concentration* }\end{array}$ & $\begin{array}{c}\text { Fat content } \\
(\%)\end{array}$ \\
\hline For food & Inside ham & 1.00 & 5.95 \\
& Outside ham & 0.88 & 18.7 \\
& Picnic shoulder & 0.85 & 9.12 \\
& Fillet & 0.81 & 8.75 \\
& Boston butt & 0.62 & 41.3 \\
& Loin & 0.46 & 31.0 \\
& Belly & 0.28 & 61.4 \\
\hline \multirow{2}{*}{ thers } & Hind leg & 0.96 & 10.2 \\
& Around the neck & 0.81 & 14.4 \\
& Foreleg & 0.77 & 2.87 \\
& Under the neck & 0.65 & 27.6 \\
& Rump & 0.54 & 40.8 \\
& Around the rump & 0.26 & 63.1 \\
& Abdomen & 0.20 & 72.2 \\
\hline & Abdomen (fat only) & 0.05 & 86.3 \\
\hline
\end{tabular}

* The ratio of concentration between inside ham and each part.

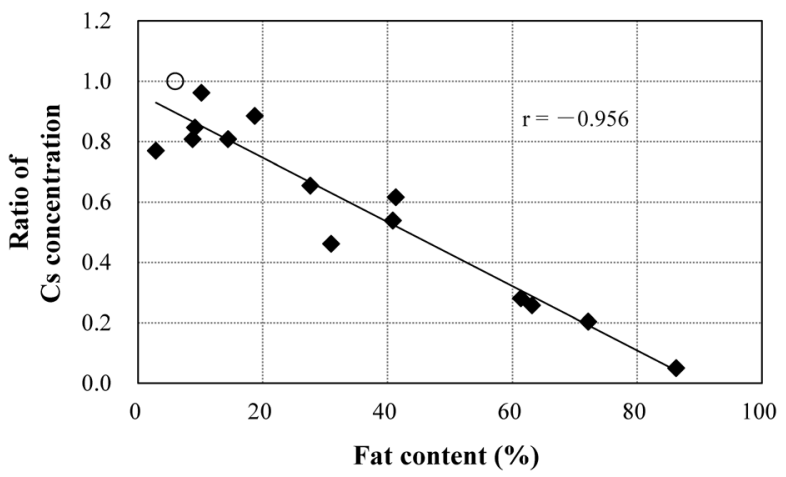

Fig. 2. Relation between ratio of $\mathrm{Cs}$ concentration (inside ham $=1.0)$ and fat content in wild boar meats

$\bigcirc$, Concentration of inside ham; $\diamond$, Other parts

るという既報 ${ }^{6)}$ と同様の結果が，イノシシ肉においても得 られた。

Cs は水溶性であり, 脂質への蓄積は少ないと考えられ る。そのため, 各部位の $\mathrm{Cs}$ 濃度は各部位ごとの脂質含有 割合に影響されると考えられる。そこで，筋肉のみでの Cs 濃度の比較を行うため, 脂肪除去後検体を用いて同様 の検討を行った。 その結果を Table 4 に示した. Cs 濃度が 最も高い部位は後脚で, 最も低い部位はロースであった。 14 部位全体の Cs 濃度平均值とその標準偏差から判断する と, Cs 濃度の部位間の差はないと考えられた。脂肪除去 後検体は脂質含有量の範囲が狭く (1.61〜 5.26\%), 脂肪 除去前検体と同様に評価できないが, Cs 濃度比と脂質含 有量の関係は, 相関係数 $r=-0.096(n=14, p>0.05)$ と なり相関は認められなかった。牛では胸最長筋（ロース）, 大腿二頭筋（外モモ）の Cs 濃度に有意差はないという報 告7) があり, 今回検討したイノシシ肉においても同様の結 果が得られた。

本検討結果では, 脂肪除去前検体の食用部位の中でモモ
Table 4. The ratio of $\mathrm{Cs}$ concentration and fat content in each part of wild boar meat (fat removal processing)

\begin{tabular}{llcc}
\hline \hline Part & $\begin{array}{c}\text { Ratio of Cs } \\
\text { concentration* }\end{array}$ & $\begin{array}{c}\text { Fat content } \\
(\%)\end{array}$ \\
\hline For food & Inside ham & 1.00 & 2.36 \\
& Outside ham & 1.04 & 2.87 \\
& Picnic shoulder & 0.89 & 1.92 \\
Fillet & 0.79 & 2.43 \\
Boston butt & 0.86 & 4.24 \\
& Loin & 0.61 & 2.10 \\
Belly & 0.82 & 5.26 \\
\hline Others & Hind leg & 1.14 & 2.59 \\
& Around the neck & 0.86 & 4.41 \\
& Foreleg & 0.71 & 1.61 \\
Under the neck & 0.82 & 3.68 \\
Rump & 1.00 & 2.21 \\
Around the rump & 0.82 & 3.93 \\
Abdomen & 0.75 & 4.17 \\
\hline
\end{tabular}

* Symbol is as in Table 3.

肉が最も高い Cs 濃度を示したことから，イノシシ肉の Cs 検査対象部位としてモモ肉を使用することに関しては，お おむね妥当であると考えられた。

ま とめ

イノシシ肉の精密検査の結果, 20 検体中 4 検体から一般 食品の基準值を超える Cs 濃度が検出されたが，シカ肉の モニタリング検査では基準值を超えたものはなかった。食 用に供されるイノシシ肉については，今後も継続的な調査 が必要と考えられた。

イノシシ肉の左半身を 14 部位に分け, Cs 濃度と脂質含 有量を求めた。 その結果, 脂肪除去前検体の食用部位の中 でモモ肉が最も高い $\mathrm{Cs}$ 濃度を示したことから，検査対象 部位としてモモ肉を使用することに関しては，おおむね妥 当であると考えられた。

国および地方公共団体は，農作物の被害防止対策を持続 的に実施するため, 捕獲されたイノシシ等の野生鳥獣を地 域資源と捉え, 食品としての利用を推進している*9. イ ノシシ肉における部位別の $\mathrm{Cs}$ 濃度についての報告はこれ までなく, 今後, イノシシ肉の公衆衛生上の安全な有効活 用を実施するために，個体数などを増やし，詳細な検討を 行っていく予定である.

\section{文献}

1) Furubayashi, K., Maruyama, N. Food habits of sika in Fudakake, Tanzawa mountains. Honyu Dobutsugaku Zasshi (The Journal of the Mammalogical Society of Japan), 7, 55-62 (1977).

2) Hasegawa, M., Ito, M., Kaneko, S., Kiyono, Y., Ikeda, S.,

*9 鳥獣による農林水産業等に係る被害の防止のための施策を実 施するための基本的な指針，農林水产省告示第1396号（平 成 27 年 5 月 29 日） 
Makino, S. Radiocesium concentrations in epigeic earthworms at various distances from the Fukushima Nuclear Power Plant 6 months after the 2011 accident. Journal of Environmental Radioactivity, 126, 8-13 (2013).

3) Koba, Y., Sakaguchi, M., Muraoka, R., Obitsu, T., Tanida, H. Food habitat of wild boars in Kami-Kamagari Island in Hiroshima. Honyurui Kagaku (Mammalian Science), 49, 207-215 (2009).

4）日本アイソトープ協会. アイソトープ手帳11版. 東京, 丸善, 2011, p. 63-64. (ISBN 978-4-89073-211-1)

5) Semizhon, T., Putyrskaya, V., Zibold, G., Klemt, E. Time-dependency of the ${ }^{137} \mathrm{Cs}$ contamination of wild boar from a region in Southern Germany in the years 1998 to 2008. Journal of Environmental Radioactivity, 100, 988992 (2009).

6) Nabeshi, H., Kikuchi, H., Tsutsumi, T., Hachisuka, A., Matsuda, R. Concentrations of radioactive cesium in different cuts of beef. Shokuhin Eiseigaku Zasshi (Food Hyg. Saf. Sci.), 54, 415-418 (2013).

7) Fukuda, T. et al. Distribution of artificial radionuclides in abandoned cattle in the evacuation zone of the Fukushima Daiichi Nuclear Power Plant. PLOS ONE, 8, e54312 (2013). 